\title{
Management values at the Southern Sun Group
}

\author{
A. Thomas* \\ Graduate School of Business Administration \\ University of the Witwatersrand, PO Box 98, Wits 2050, Republic of South Africa \\ adelet@megaweb.co.za \\ M. Turpin \\ Graduate School of Business Administration, \\ University of the Witwatersrand, PO Box 98, Wits 2050, Republic of South Africa
}

Received June 2002

\begin{abstract}
South African companies need to become increasingly competitive and productive in the global economy while complying with the statutory requirements of a range of labour legislation. Implementation of the requirements of the Employment Equity Act is likely to result in greater diversity within companies and increasing representation of different race groups at all levels. As management practices may need to be tailored to harness, for competitive advantage, the diverse values that employees bring to the workplace, it was the objective of the present exploratory study to measure similarities and differences in values for managers in the Southern Sun Group, a prominent hotel group in South Africa. The methodology involved obtaining a convenience sample of 68 managers from three race groups, and having them complete the VSM94 instrument (Hofstede, 1994) with the aim of investigating similarities and differences in values between such groups. The findings indicate that managers in the sample evidence both similar and different values along the Hofstede (1994) values dimensions. The study addresses the implications for the Southern Sun Group of managing an increasingly diverse workforce. Where differences in value orientations are apparent, recommendations are made to the management of the Southern Sun Group as to how management practices could be adapted to effectively respond to these differences.
\end{abstract}

*To whom all correspondence should be addressed.

\section{Introduction}

Since the early 1990s, South African companies have had increasing opportunities to compete internationally, both by expanding their operations outside South African borders through international exports, as well as by addressing competition from foreign companies investing in the country. The competitiveness of the South African economy (which, in effect, means the competitiveness of South African companies) has, as a result, become a matter of increasing interest and concern. South Africa has been placed $42^{\text {nd }}$ out of 49 industrialised countries in the rankings contained in the World Competitiveness Yearbook published annually by the International Institute for Management Development (IMD, 2001), and this position has not changed much in the past five years.

In both the public and private sectors, employment practices at South African companies during the apartheid era systematically discriminated against black and women employees. Van der Westhuizen (1998) indicates the extent of under-representation of black people and women in management positions (i.e. from director level upwards) in the public sector prior to 1996. Only six percent of this echelon was black and only five percent were women. In the private sector, the Breakwater Monitor Project
Millennium Edition (2000) in which more than 160 South African organisations were reviewed, indicates that management levels are still largely occupied by whites ( 80 percent), and by men (79 percent). The report suggests that progress in implementing affirmative action in companies to address inequality of representation has, since 1991, been far less significant than is claimed in company statements. Accordingly, the South African government has, since 1994, accorded priority to redressing the years of workplace discrimination. In addition to introducing legislation aimed at protecting workers' rights, the government has enacted laws aimed at eliminating unfair discrimination, promoting equity in the workplace and providing for a statutory levybased system for skills development for working and unemployed people. The Employment Equity Act (Republic of South Africa, 1998) has proved to be one of the more contentious laws impacting on the workplace and is one which is designed to accelerate the appointment and promotion of people who have historically been discriminated against in the workplace. Critics of this Act, in particular, and the South African legislative labour environment, in general, have argued that such legislation will adversely affect the economy in the long-term (Dickman, 1998; Jafta, 1998). Given, however, that companies are compelled to comply with legislative requirements, the challenge now becomes one of harnessing 
the potential of all employees who increasingly, particularly at managerial levels, constitute the new diverse workforce.

Within the hotel and leisure industry, the Southern Sun Group employs over 5,500 permanent staff. The Group prides itself on having been the first company in South Africa to submit its employment equity report to the Department of Labour in compliance with its obligations under the Employment Equity Act (Republic of South Africa, 1998). It also espouses positive values regarding its employees and indicates that it is working to eliminate barriers to the full utilisation of employee diversity in all its workplace practices. To this end it has adopted an approach of full compliance with even the minutiae of the Act. Southern Sun may be unusual in this practice. Louw (2000) reports on a study of the first companies to submit their employment equity reports to the Department of Labour, in which it is noted that employment equity programmes are generally not accompanied by initiatives to address cultural diversity in the workplace.

With strategies to achieve employment equity, it can be expected that employees from a variety of cultural and ethnic backgrounds and a greater number of women will increasingly occupy management positions. Given that such diversity may introduce a multiplicity of values into workplaces (Sikula \& Sikula. 1975) previously characterised by homogeneity, it is perhaps pertinent to investigate the possibility of the existence of diverse values amongst managers in a South African company with a view to understanding this particular dimension of diversity and its possible implications for human resources practices. Accordingly, the present study explored the extent to which managers from three cultural (racial) backgrounds within the Southern Sun Group, evidenced similar or different values and the possible implications thereof.

\section{Literature review}

\section{National values}

Newman and Nollen (1996) note the increasing acceptance of the idea that managerial attitudes, values, behaviours and efficacy differ across national boundaries. This idea was given prominence as a result of the extensive research conducted by Hofstede (1980) in which he surveyed over 116000 IBM employees from 40 different countries between 1967 and 1973 . Hofstede $(1980 ; 1994)$ found that work-related values vary according to dimensions of national culture.

Hofstede (1980) recognises that cultures and nations are not necessarily equivalent, but also recognises the persistent influence of a majority value system. Hofstede (1980:25) refers to culture as 'the collective programing of the mind which distinguishes one human group from another ... Culture in this sense includes systems of values; and values are among the building blocks of culture'. Hofstede (1991) further describes values as a fundamental manifestation of culture.

Zurcher, Meadow and Zurcher (1965:539) define a value as 'a selective orientation toward experience, implying deep commitment or repudiation, which influences the ordering of choices between possible alternatives in action'. Rokeach (1973) notes that values are not directly equivalent to needs or attitudes. Sikula and Sikula (1975) and Godsell (1983) have researched values across races and comment on differences in this regard.

The five basic values dimensions identified by Hofstede $(1980 ; 1997)$ for differentiating between cultures are:

- power distance (PDI), which 'indicates the extent to which a society accepts the fact that power in institutions and organizations is distributed unequally' (Hofstede, 1980:45);

- individualism/collectivism (IDV), which describes 'the relationship between the individual and the collectivity which prevails in a given society' (Hofstede, 1997:148);

- uncertainty avoidance (UAI), which indicates 'the extent to which a society feels threatened by uncertain and ambiguous situations and tries to avoid these situations by providing greater career stability, establishing more formal rules, not tolerating deviant ideas and behaviors, and believing in absolute truths and the attainment of expertise' (Hofstede, 1980:45);

- masculinity/femininity (MAS), by which 'masculine cultures use the biological existence of two sexes to define very different social roles for men and women. They expect men to be assertive, ambitious and competitive, to strive for material success, and to respect whatever is big, strong and fast. They expect women to serve and to care for the non-material quality of life, for children and for the weak. Feminine cultures, on the other hand, define relatively overlapping social goals for the sexes, in which neither men nor women need to be ambitious or competitive' (Hofstede, 1984:390); and

- long-term orientation versus short-term orientation (LTO): 'A society with a long-term orientation fosters virtues oriented towards future rewards, in particular perseverance and thrift. A short-term orientation is found in societies which foster virtues related to the past and present, in particular respect for tradition, preservation of 'face' and fulfilling social obligations' (Hofstede, 1997:167).

\section{Organisational values}

Discussing values at an organisational level, Deal and Kennedy (1982: 34) suggest that 'the power of values is that people care about them', while Kotter (1996:148) identifies shared values as significant because they 'tend to shape group behavior and ... persist over time even when group membership changes'. Similarly, Peters and Waterman (1984) and Lagan (1998) argue that a common set of values should become the philosophy that drives behaviour and decision-making in any organisation. Such values, when repeatedly applied successfully to the addressing of problems in an organisation, become translated into Schein's (1992) basic assumptions that form the foundations of organisational culture. Such assumptions, in turn, 
promote the development (or not) of high performance work cultures (Kotter \& Heskett, 1992; Blanchard \& O’Connor, 1997).

Organisational culture can be thought of as the glue that binds together the collective workings of an organisation and its people through a shared understanding of patterns of meaning (Siehl \& Martin, 1984). It is a powerful force of unwritten rules and associated norms that governs the way people should behave in organisations, which has been developed through the years by organisational leaders and transmitted throughout the organisation in a variety of overt and covert ways (Kotter \& Heskett, 1992). It is reinforced by rewards and punishments, and determines who is included in the inner circle of the organisation and who is left on the periphery. Broadly, the concept 'culture' represents 'an interdependent set of values and ways of behaving that are common in a community and that tend to perpetuate themselves, sometimes over long periods of time' (Kotter \& Heskett, 1992: 141).

The significance of Hofstede's (1980; 1997) values dimensions on business performance has been explored in various contexts. Russell (2001) states that there is empirical support for a relationship between cultural variables and economic outcomes. Hofstede (1997) notes how interventions in the workplace will fail if they do not appreciate the values of the intended beneficiaries. Similarly Jackson and Bak (1998) query the simple implementation of management practices developed abroad that take no account of local cultural values. Newman and Nollen (1996) explored the relationship between Hofstede's $(1980,1991)$ five values dimensions and analogous management practices and concluded that work unit performance is higher when management practices are aligned with the relevant cultural value dimension for four of the five dimensions (the hypothesis was only partially supported in the case of uncertainty avoidance).

In South Africa, specifically, commentators such as Brehm (1994) and Boon (1997) often represent 'western' values (generally those held by white South African managers) as being opposed and different to African values in the workplace. Mthembu (1996) argues that colonialism has eroded indigenous African values. Khoza (1993) and Koopman (1991) propose that South African management practices are strongly reflective of British and American systems, thinking that has led to the call, by some, for an 'Afrocentric' management approach (Mbigi \& Maree, 1995; Boon, 1997; Mthembu, 1996). Such an approach in the workplace would encompass the underlying values of ubuntu where the collectivist notion of interdependence of people is recognised and respected. In contrast, Thomas and Schonken (1998a) have cast doubt on the notion of the value of a distinct form of African-value based management, as opposed to more 'Eurocentric' styles of management. Similarly, Marais (2001) states that black and white business leaders in South Africa broadly share a common set of ideological principles while Thomas and Bendixen (2000) note the similarity of values of middle managers of all ethnic groups in their South African study.

\section{Diversity in the workplace}

When thinking about national values in relation to Hofstede (1997), and when considering the cultural, ethnic, religious and gender diversity evident in the South African workplace, Thomas and Bendixen (2000) hypothesise that a multitude of ethnic values could exist within diverse employee groupings.

One of the most widely utilised tools for measuring cultural values is the VSM 94 instrument developed by Hofstede (1994). This instrument has previously been used for the measurement of values for 586 middle managers in South Africa (Thomas \& Bendixen, 2000). While the questions contained in this instrument are normally used for drawing comparisons between countries, the use in the South African context by Thomas and Bendixen (2000) was based on the hypothesis that different ethnic groups in the country could evidence different or similar values. In this vein, these researchers undertook an intra-country group comparison similar to that effected between countries.

The link between the effective management of workplace diversity and improved business performance is of increasing academic interest and there is a growing body of evidence in support of such a link. Wright, Ferris, Hiller and Kroll (1995) indicate the existence of a positive market reaction to workplace diversity initiatives in the United States. Cox and Beale (1997:18) argue that 'although legal and moral motives are still strong factors in organizational change work on diversity, the motive that is by far the most prominently cited in organizations active in this area is to improve organizational performance on the traditional goals of revenue growth, profitability, and maximization of resource utilization in pursuit of the organizational mission'. They then suggest that the recognition of cultural differences, and by extension, it could be argued, cultural values within the workplace is a key to organisational effectiveness.

The question arises as to what extent corporate cultures need to respond to people of different racial and ethnic groups (together with their possible similarities and differences in values) that increasingly make up the workforce.

Tsui, Egan and O'Reilly (1992:568) explored the relationship between demographic factors and organisational commitment, and conclude that 'the greater the difference in race between an individual and all other individuals in a work unit, the lower the individual's attachment to the organization'. Similarly, Thomas and Doak (2000) point out that employees who do not feel part of an established organisational culture are likely to display a lower level of overall commitment to the organisation. Wadula (1997) has illustrated what has become known as the 'revolving door' syndrome, in which black managers join and leave South African companies after remaining only for short periods, a reason being that the culture in many companies is not conducive to fully including all members of a diverse workforce. Motshabi (1991) argues for companies to create an atmosphere within which the diversity of employees can be utilised in the achievement of organisational goals. 


\section{Southern Sun hotels}

Southern Sun Hotels (Southern Sun) is a division of Southern Sun Holdings, a wholly owned subsidiary of South African Breweries. Southern Sun has a portfolio of 81 hotels in southern Africa and describes itself as 'Africa's leading hotel group'. There is also a gaming division that operates casinos. The vision of Southern Sun Hotels (2001) is as follows:

'We aim to anticipate and satisfy the needs of hotel guests and become the best hotel group in Africa by any recognised measure by 2005, achieving this goal by providing quality products and services within a range of viable brands, through the efforts of well-trained and motivated people'.

Southern Sun espouses a range of group values and commitments relating to customers, people, quality, performance and innovation. The group value relating to 'Our People' states that, 'we aim to create and sustain a working environment that provides job satisfaction and the development of each person's full potential' (Southern Sun Hotels, 2001).

The hotel division employs around 4,000 permanent staff, with a further 1,600 permanent employees in the gaming division. Forty six percent of the employees are members of trade unions. Fifty-four percent of the hotel employees have been employed at the company in excess of 10 years, and 34 percent for more than 15 years (Southern Sun Group Corporate Citizen Report, 2000). Southern Sun seeks to be recognised by its stakeholders as the employer of choice in the hotel industry in all the countries in which it has a presence.

Southern Sun is committed to employment equity and nondiscriminatory human resources practices, and 'respects the diverse and multi-cultural interests of all stakeholders' (Southern Sun Group Corporate Citizen Report, 2000). The company regularly conducts reviews of company policies and procedures to encourage employee diversity and to prevent potential unfair discrimination from arising in the workplace.

The percentages of executive and managerial staff from previously disadvantaged groups as at $31^{\text {st }}$ March 2000 were recorded as follows:

Table 1: Race and gender according to management level

\begin{tabular}{l|l|l}
\hline & Black* $^{*}$ & Female \\
\hline Executive Level & $8.7 \%$ & $14.5 \%$ \\
\hline Senior Management & $6.2 \%$ & $18.8 \%$ \\
\hline Junior \& Middle Management & $38.4 \%$ & $44.0 \%$ \\
\hline
\end{tabular}

Source: Southern Sun Group Corporate Citizenship Report (2000)

- extract

* includes Africans, Indians and Coloureds
A total of 34 disabled persons are employed (one percent of the total workforce in the company) (Southern Sun Group Corporate Citizenship Report, 2000).

Southern Sun has allocated the equivalent of almost six percent of its payroll costs per annum over the past five years to training and development. As further evidence of commitment to employees, the company indicates the number of housing loans provided and its support for employees who are HIV-positive (Southern Sun Group Corporate Citizenship Report, 2000).

As Southern Sun advances with its employment equity plans, different ethnic groups from within South Africa will increasingly be represented at managerial levels. These managerial levels will then include representatives of what could be described as different 'sub-national' cultures who may bring different sets of values into the company (Lenartowicz \& Roth, 2001).

A question that might then arise for Southern Sun is whether the existing corporate culture of the company is able to incorporate, sustain and value this diversity, and what management practices will be needed to ensure the retention, contribution and growth of new managers from diverse backgrounds who may evidence values that are similar to or different from one another.

\section{Methodology}

The present study aims to identify whether or not managers in the company from three different ethnic backgrounds subscribe to different values as measured by the Hofstede VSM94 instrument (Hofstede, 1994).

Based on the literature review, and in line with the study conducted by Thomas and Bendixen (2000), the following proposition was posited:

\section{Mangers of different ethnic groups at Southern Sun embrace different values.}

If the proposition is supported by the findings, it could suggest a challenge for the management of Southern Sun in addressing its corporate culture and related management practices to ensure that managers, holding diverse values, operate within a work environment that promotes their optimal performance. If, on the other hand, the proposition is not supported, and managers within the company are shown to embrace broadly similar values, the challenge would be to align management policies and practices with the prevailing managerial value system. At the heart of this proposition is the question - can a distinct South African culture be observed, as evidenced by similar values, amongst managers in South African organisations, or are there distinct sub-cultures that may pose particular challenges for the creation of inclusive corporate cultures and fair management practices?

\section{Population and sampling}

The population comprised all managers employed at the Southern Sun Group. Managers were determined to be 
those who have responsibility for or involvement in the hiring or firing of staff, a definition employed by Thomas and Bendixen (2000).

A total of 79 managers was selected for the study by the Human Resources department at Southern Sun according to convenience sampling, as directed by the researchers. Leedy (1997:204) describes convenience sampling, which makes no pretence of being representative of the population, as a method used when 'the researcher has no way of forecasting, estimating, or guaranteeing that each element in the population will be represented in the sample'.

In line with the requirements of Hofstede (1994), a minimum of 20 respondents from each of the following racial/ethnic groups were targeted, with no more than five respondents being sampled from any one hotel:

- $\quad$ black managers (Zulu, Xhosa or Sotho-speaking);

- $\quad$ white managers (English or Afrikaans-speaking);

- Indian managers (any language).

Managers to be included in the sample were selected from 20 hotels in Gauteng and KwaZulu Natal as well as from the Southern Sun Head Office and the Regional Office in KwaZulu Natal. The study did not attempt to address values according to gender and therefore no sampling occurred on the basis of gender within the different race groups. Difficulty was also experienced in obtaining a minimum sample of Coloured managers as required by Hofstede (1994), and accordingly, the study excludes this group.

Of the 79 managers selected, 68 participated in the study with the requisite minimum number of 20 from each group being achieved.

\section{Data collection and analysis}

In each case, respondents completed the questions contained in the VSM94 instrument (Hofstede, 1994) in the presence of one of the researchers during October and November 2001 .

The results were analysed according to the standardised scoring format provided by Hofstede (1994) in order to identify the value dimension rankings for each ethnic group.

\section{Limitations of the study}

In the interpretation of the findings of the present study, the following limitations should be considered:

1. The study has been confined to one particular company and accordingly, the findings cannot be generalised to all South African companies;

2. The difficulty of obtaining sufficient numbers of male and female respondents in each race group, as required by Hofstede (1994), has prohibited any conclusions being drawn about differences between the genders within each group;
3. The difficulty in obtaining sufficient numbers of Coloured managers to meet the requirements of Hofstede (1994) has resulted in the omission of this group from the study, again with attendant implications for the generalisability of the findings;

4. A convenience sample of managers was drawn for inclusion in the present study. Such a sample may not be representative of the managers of the company, and accordingly, even in the interpretation of the findings with regard to the specific company under investigation, such interpretation must be undertaken with caution.

\section{Results}

The results are presented in Table 2 below.

Table 2: Value dimension score by ethnic group and gender

\begin{tabular}{l|c|c|c|c|c|c}
\hline Group & $\begin{array}{c}\text { Sample } \\
\text { Size }\end{array}$ & PDI & IDV & MAS & UAI & LTO \\
\hline White & 27 & 25.5 & 90.3 & 58.3 & 34.9 & 51.5 \\
\hline Indian & 20 & 38.5 & 91.7 & 16.0 & 21.0 & 36.0 \\
\hline African & 21 & 15.0 & 67.8 & -4.6 & 53.5 & 55.1 \\
\hline Male & 37 & 31.3 & 88.4 & 6.2 & 26.8 & 49.5 \\
\hline Female & 31 & 22.4 & 81.6 & 53.1 & 47.7 & 49.0 \\
\hline Total & 68 & 26.6 & 86.0 & 29.2 & 36.7 & 48.8 \\
\hline
\end{tabular}

Overall, the findings indicate that while there is general similarity on the value dimensions between the white and Indian groups, the African group tends to evidence differences from these two groups on all but the LTO dimension. Other differences will be discussed below. This finding supports that of an earlier South African study undertaken by Thomas and Schonken (1998b). The results of the present study therefore indicate that the existence of common values amongst managers at Southern Sun cannot be assumed and the previously-stated proposition is therefore only partially supported.

Managers scored consistently low on the PDI dimension (with African managers scoring lowest of all). Scores for all were consistently high on the IDV dimension (with African managers, however, scoring lowest on this dimension), while those for the LTO and UAI dimensions were consistently average (although African and female managers scored higher on the UAI dimension than did other groups).

The dimension that evidenced the greatest variance was the MAS dimension, with white and female managers scoring higher than the other groups, and African managers scoring lowest of all. The Indian and African groups evidence low scores on this dimension, with the African group evidencing a negative score. 
The values of managers in the sample can be described as follows:

$\begin{array}{lll}\circ & \text { PDI } & \text { low } \\ \circ & \text { IDV } & \text { high (but lower for the African group) } \\ \circ & \text { MAS } & \begin{array}{l}\text { low (except for the white and female groups) } \\ \text { average (except for African and female } \\ \text { groups) }\end{array} \\ \text { UAI } & \text { LTO } & \begin{array}{l}\text { average } \\ \circ\end{array}\end{array}$

The overall results were then compared with the South African results from the original international study by Hofstede (1980) (in which only South African white males were included) and with the study by Thomas and Bendixen (2000). These comparisons are presented in Table 3:

Table 3: Comparison of present results with Hofstede (1980) and Thomas and Bendixen (2000)

\begin{tabular}{l|c|c|c|c|c}
\hline Study & PDI & IDV & MAS & UAI & LTO \\
\hline $\begin{array}{l}\text { SA - original by } \\
\text { Hofstede (1980) }\end{array}$ & 49 & 65 & 63 & 49 & - \\
\hline $\begin{array}{l}\text { SA - Thomas and } \\
\text { Bendixen (2000) }\end{array}$ & 1 & 81 & 34 & 48 & 45 \\
\hline Present study & 27 & 86 & 29 & 37 & 49 \\
\hline
\end{tabular}

The results indicate some broad similarities between the three studies. The low PDI result in the present study is consistent with the Thomas and Bendixen (2000) finding and halfway between that of Hofstede (1980). The low PDI score is accompanied by a high IDV score, consistent with Thomas and Bendixen (2000), while the scores on the other dimensions in the present study are not very different from the earlier studies.

\section{Discussion}

The low PDI score across all groups indicates reluctance amongst managers at Southern Sun to accept the unequal distribution of power. This is especially so in the case of the African group (PDI $=15)$, and least so in the case of the Indian group (PDI $=38$ ). This finding implies that managers at Southern Sun, in general, and particularly African managers, prefer not to work in an environment that is characterised by great hierarchy. Thomas and Bendixen (2000:513) posited an explanation for low PDI scores in their study as being related to recent political changes in South Africa, with the associated political climate that promotes participation and democratic decision-making. The fact that the African group scores lowest of all on this dimension might tend to support this theory, as it could be argued that they would be more likely to be aligned with this new culture as a result of having been most excluded from political (and managerial) decision-making in the past. The low score on this dimension may give some credibility to the Afrocentric theories of Mbigi and Maree (1995) and Boon (1997), at least inasmuch as they indicate a need for democracy and transparency in the workplace.
The high scores on the IDV dimension are especially marked in the case of the Indian and white groups, indicating a strong preference for valuing individual action and management practices that support individual effort as opposed to collectivist approaches. The African group's slightly lower score (IDV $=67.8$ ), while still above average, indicates that this group might be more open to collective ways of working, as well as possibly less tolerant of individual-based reward systems linked to performance management. It appears, nonetheless, that the managerial group, as a whole, places high value on individualism. Thomas and Bendixen (2000), however, raise a question as to whether Hofstede's (1994) VSM94 instrument is adequate in distinguishing between individualism and communalism (possibly typified by the concept of ubuntu) in the South African management context as opposed to collectivism that may be tapped by the VSM94 (see Shutte, 1996).

The MAS dimension is the one that evidences the greatest variation between the groups. The white and female groups score on the upper end of the scale, indicating that the white and female managers are more likely to embrace distinct gender roles and embrace material success. On the other hand, the African group registers a particularly low score, indicating a preference for overlapping gender roles and a strong concern with quality of life. These managers would tend to prefer working in a caring, supportive environment that may be captured in the concept of ubuntu (Mbigi \& Maree, 1995).

On the UAI dimension, African and female managers score higher than the other groups indicating a stronger preference for structure and certainty. In contrast, white, Indian and male managers probably feel relatively more comfortable operating in ambiguous or changing situations.

The LTO dimension indicates no major differences between the three groups, although the Indian group has the lowest score, indicating a greater preference for values of tradition and social obligation.

\section{Conclusion and recommendations}

The recommendations of this study are based on the assumed value, as articulated by Newman and Nollen (1996) and Jackson and Bak (1998), of attempting to achieve alignment of management practices within Southern Sun with the identified values held by the different groups who comprised the sample. Based on the interpretation of the findings of the present study, the following recommendations are made to the management of Southern Sun.

The first recommendation relates to the low PDI scores. The recommendation is that the management of Southern Sun should promote a culture of participative decisionmaking within the managerial group. Although the Indian group may prove to be marginally less supportive of this approach, it is likely to be generally welcomed by all groups, and will most probably receive strong support from the African group in particular. While not every decision can be made in a fully collective and democratic way, nonetheless there is likely to be merit in ensuring a high 
level of transparency in decision-making and enabling input to be gained regarding decisions, from people likely to be affected by such decisions.

The second recommendation relates to the high scores on the IDV dimension. While, in general, the management of Southern Sun can be confident in emphasising individual work performance, management should be aware that a lower score was obtained on this dimension for the African group, indicating lower levels of support for the emphasis on individual effort as distinct from group contributions and teamwork. As Southern Sun advances with its employment equity plans, it might be important to consider, increasingly, how management might reward group effort as well as individual performance.

The third recommendation relates to the higher score for the white and female managers and the low scores for Indian and, and particularly, African managers on the MAS dimension. This may indicate the need for the management of Southern Sun to consider carefully how it approaches the question of rewarding performance. White and female managers may be more comfortable with merit-based reward systems that offer higher earnings and promotion linked to good individual performance. This finding is even more pertinent when linked to the finding relating to the high IDV scores noted earlier. The other groups, particularly African managers, may prefer working within a culture that recognises the value of interpersonal relations and teamwork, and one that is more tolerant of individual failure. Management at Southern Sun will also need to consider carefully how it balances a concern with task (outputs) with the need to develop processes that have broad acceptance (achieving the end result in a way that values both the team and the individual contributions of participants).

The fourth recommendation is made in terms of the UAI dimension, where the African and female groups scored at a higher level than the other groups. This may indicate that managers in these groups evidence a greater need for structure and certainty in the workplace. Where new African and female managers are introduced into the company, possibly in terms of addressing target setting as a part of an employment equity plan, a case can be made for the development of formal, structured mentoring and support programmes to enable these new managers to integrate effectively into the company and to learn what Schein (1992) would call the underlying assumptions of the culture. It is suggested that management should also consider carefully how change is introduced within the company and how different groups may respond to such change. If change strategies are unavoidable, they will need to be managed in as structured and predictable a manner as possible so that particular groups do not feel marginalised in the process.

While legislative requirements will ensure that South African companies, particularly at management levels, become increasingly diverse, it is suggested that the challenge now becomes translating such diversity into competitive advantage. An understanding of the value dimensions evidenced by a diverse group of employees may shed light on management practices that could best harness such values towards the achievement of organisational objectives and the creation of organisational cultures that are fully inclusive of diverse employees. One of the limitations of the present study is that it was confined to one particular hotel group. The hotel and hospitality industry is of vital importance in terms of its potential for job creation and economic development in South Africa, and, accordingly, exploration of opportunities for improved economic performance in this industry is of interest. A suggestion for further research is that this study is extended to other hotel groups to further explore the issues of diversity and value orientations.

\section{References}

Blanchard, K. \& O’Connor, M. 1997. Managing by values. San Francisco: Berrett-Koehler.

Breakwater Monitor Project - Millennium Edition 2000. Cape Town: Graduate School of Business, University of Cape Town.

Boon, M. 1997. The African way - the power of interactive leadership. Sandton: Zebra Press.

Brehm, N.L. 1994. 'The impact of South African culture on the management of people'. Unpublished MM Research Report. Johannesburg: University of the Witwatersrand.

Cox, T.H. \& Beale, R.L. 1997. Developing competency to manage diversity. San Francisco: Berrett-Koehler.

Deal, T.E. \& Kennedy, A.A. 1982. Corporate cultures: The rites \& rituals of corporate life. Massachusetts: AddisonWesley.

Dickman, J. 1998. 'Employment Equity Bill: SACOB'S viewpoint', Accountancy SA, July.

Godsell, G. 1983. Work value differences in South African organisations: A study and some conclusions. CSIR NIPR Special Report PERS 359. Johannesburg: National Institute for Personnel Research.

Hofstede, G. 1980. Culture's consequences: international differences in work related values. Beverly Hills: Sage.

Hofstede, G. 1984. 'The cultural relativity of the quality of life concept', Academy of Management Review, 9 (3): 389-98.

Hofstede, G. 1991. Cultures and organizations - software of the mind. New York: McGraw Hill.

Hofstede, G. 1994. Value survey module 1994: Manual. Maastricht: Institute for Research on Intercultural Cooperation.

Hofstede, G. 1997. Cultures and organizations: software of the mind. New York: McGraw-Hill. 
Institute for Management Development (IMD). 2001. World Competitiveness Yearbook. Lauzanne: IMD. [online] URL:http://www.imd.ch/wcy/ranking/ranking.html.

Jackson, T. \& Bak, M. 1998. 'Foreign companies and Chinese workers: Employee motivation in the People's Republic of China', Journal of Organizational Change Management, 11(4): 282-300.

Jafta, R. 1998. 'The high cost of affirmative action', Focus, April.

Khoza, R. 1993. 'The need for an Afrocentric management approach'. In Christie, P., Lessem, R. \& Mbigi, L. (Eds). African management - philosophies, concepts and applications. Randburg: Knowledge Resources: 117-24.

Koopman, A. 1991. Transcultural management: How to unlock global resources. Cambridge: Basil Blackwell.

Kotter, J.P. 1996. Leading change. Boston: Harvard Business School Press.

Kotter, J.P. \& Heskett, J.L. 1992. Corporate culture and performance. New York: The Free Press.

Lagan, P.A. 1998. 'Recognising the value in values', $H R$ Monthly, August: 28-29.

Leedy, P. D. 1997. Practical research: Planning and design. 6th Edition. New Jersey: Prentice-Hall Inc.

Lenartowicz, T. \& Roth, K. 2001. 'Does subculture within a country matter? A cross-cultural study of motivational domain and business performance in Brazil', Journal of International Business Studies, 32(2):305-25.

Louw, I. 2000. 'Employers fall short on cultural diversity', Business Day, 9 November: 3.

Marais, H. 2001. South Africa: Limits to change - the political economy of transition. Cape Town: UCT Press.

Mbigi, L. \& Maree, J. 1995. Ubuntu - the spirit of African transformation management. Randburg: Knowledge Resources.

Motshabi, K.B. 1991. 'Managing cultural diversity in a multiracial workplace'. In Human, L. (Ed). Educating \& developing managers for a changing South Africa. Cape Town: Juta.

Mtembu, D. 1996. 'African values: discovering the indigenous roots of management'. In Lessem, R. \& Nussbaum, B. (Eds). Sawubona Africa - embracing four worlds in South African management. Sandton: Zebra Press: 215-26.

Newman, K.L. \& Nollen, S. 1996. 'Culture and congruence: The fit between management practices and national culture', Journal of International Business Studies, 27(4):753-79.
Peters, T. \& Waterman, R. 1984. In search of excellence: Lessons from America's best-run companies. 1st Edition. New York: Warner Books.

Republic of South Africa. 1998. Employment Equity Act, No. 55. Government Gazette, No. 19370, Pretoria: Government Printer.

Rokeach, N. 1973. The nature of human values. New York: The Free Press.

Russell, R.D. 2001. 'Cultural influences on entrepreneurship: Implications for the emergence of new ventures in Latin America' unpublished paper. Harrisburg: School of Business Administration, Penn State University.

Siehl, C. \& Martin, J. 1984. 'The role of symbolic management: How can managers effectively transmit organizational culture?' In Hunt, J.D., Hosking, D., Schriesheim, C. \& Steward, R. (Eds). Leadership and managers: International perspectives on managerial behavior and leadership. New York: Pergamon.

Schein, E.H. 1992. Organizational culture and leadership. 2nd Edition. San Francisco: Jossey-Bass Publishers.

Shutte, A. 1996. Philosophy for Africa. Cape Town: UCT Press.

Sikula, J.P. \& Sikula, A.F. 1975. 'Do black and white university interns differ in their basic values?', The Journal of Negro Education, 44 (2): 200 - 7.

Southern Sun Group Corporate Citizenship Report 2000. Values and value adding. Johannesburg: Southern Sun Group.

Southern Sun Hotels 2001. [online] URL:http://www.southernsun.com.

Thomas, A. \& Bendixen, M. 2000. 'The management implications of ethnicity in South Africa', Journal of International Business Studies, 31(3):507-19.

Thomas, A. \& Doak, R. 2000. 'The development of shared values: Impact on employee behaviour and on customer perception of service', South African Journal of Business Management, 31(1):17-30.

Thomas, A. \& Schonken, J.S. 1998a. 'Culture-specific management and the African management movement - a critical review of the literature', South African Journal of Business Management, 29(2):53-66.

Thomas, A. \& Schonken, J.S. 1998b. 'Culture specific management and the African management movement verifying the premises', South African Journal of Business Management, 29(2):67-75.

Tsui, A.S., Egan, T.D. \& O'Reilly, A.C. 1992. 'Being different: Relational demographics and organizational attachment', Administrative Science Quarterly, 37:549-79. 
Van der Westhuizen, J. 1998. 'Public sector transformation and ethics: A view from South Africa', Public Money \& Management, 18(1):15-20.

Wadula, P. 1997. 'Big black staff turnover at top firms', Business Day, 5 December: 3.

Wright, P., Ferris, S.P., Hiller, J.S. \& Kroll, M. 1995. 'Competitiveness through management of diversity: effects on stock price valuation', Academy of Management Journal, 38(1):272-87.

Zurcher, L.A., Meadow, A. \& Zurcher, S.L. 1965. 'Value orientation, role conflict, and alienation from work: A crosscultural study', American Sociological Review, 30:539 - 48. 